\title{
Climatic Characterization and Temporal Analysis of Rainfall in the Municipality of Cruzeiro do Sul - AC, Brazil
}

\author{
Ednaria Santos de Araujo $^{1}$ (D), Maila Pereira de Almeida ${ }^{2}$ (D), Kelly Nascimento Leite ${ }^{3}$ (D), \\ Jefferson Rodrigues dos Santos Silva ${ }^{4}$ (D), Edson Alves de Araújo ${ }^{3}$ (D), \\ Geocleber Gomes de Sousa ${ }^{4}$ \\ ${ }^{1}$ Programa de Pós Graduação em Ciências Ambientais, Universidade Federal do Acre, Campus \\ Floresta, Cruzeiro do Sul, AC, Brazil. \\ ${ }^{2}$ Programa de Pós Graduação em Produção Vegetal, Universidade Federal do Acre, Rio Branco, \\ AC, Brazil. \\ ${ }^{3}$ Centro Multidisciplinar, Universidade Federal do Acre, Campus Floresta, Cruzeiro do Sul, AC, \\ Brazil. \\ ${ }^{4}$ Programa de Pós Graduação em Ciência, Inovação e Tecnologia para Amazônia, Universidade \\ Federal do Acre, Rio Branco, AC, Brazil. \\ ${ }^{5}$ Instituto de Desenvolvimento Rural, Universidade da Integração Internacional da Lusofonia \\ Afro-Brasileira, Redenção, CE, Brazil.
}

Received: 10 October 2019 - Accepted: 2 April 2020

\begin{abstract}
The Climatological Water Budget (CWB) determined by the Thornthwaite and Matter (1955) allows the temporal visualization of the variables that compose the climate, thus allowing the climatic characterization of a region. Therefore, this work aimed at identifying and quantifying the months of water surplus and deficit through CWB to characterize the climate for the municipality of Cruzeiro do Sul - AC, Brazil, and analyze the temporal distribution of rainfall for the municipality. We used daily precipitation and temperature values and procedures to fill in the database. We calculated the potential evapotranspiration (ETP) using the Hargreaves Samani method (1985). Subsequently, we determined the periods of soil water storage (SWS), water deficiency (DEF), and water surplus (SUR) on a monthly scale. The climate of Cruzeiro do Sul, located in the northern region of Brazil, was characterized according to the Thornthwaite (1955) as B1rA'a' for a AWC of $140 \mathrm{~mm}$, that is, a humid climate with annual rainfall average of $2227 \mathrm{~mm}$ and real evapotranspiration of $1660 \mathrm{~mm}$, with small water deficiency in the months from June to October, with no thermal deficiency, and summer concentrated in three months with an average air temperature of $25{ }^{\circ} \mathrm{C}$ ranging between $18{ }^{\circ} \mathrm{C}$ and $32{ }^{\circ} \mathrm{C}$.
\end{abstract}

Keywords: climatological water budget, climatic characterization, soil water storage, water deficit.

\section{Caracterização Climática e Análise Temporal das Chuvas no Município de Cruzeiro do Sul - AC, Brazil}

\begin{abstract}
Resumo
O Balanço Hídrico Climatológico (BHC), determinado por Thornthwaite e Matter (1955), permite a visualização temporal das variáveis que compõem o clima, identificando os períodos de déficit e excedente hídrico, permitindo a caracterização climática de uma região. Portanto, este trabalho teve como objetivo identificar e quantificar os meses de excedente e déficit hídrico por meio da BHC para caracterizar o clima do município de Cruzeiro do Sul - AC, Brasil, e analisar a distribuição temporal das chuvas no município. Utilizou-se valores e diários de precipitação e temperatura
\end{abstract}

Autor de correspondência: Kelly Nascimento Leite, knleite.ufac@gmail.com. 
para preencher o banco de dados. Calculou-se a evapotranspiração potencial (ETP) usando o método de Hargreaves Samani (1985). Posteriormente se determinou os períodos de armazenamento de água no solo (ARM), deficiência de água (DEF) e excesso de água (EXC) em uma escala mensal. O clima de Cruzeiro do Sul, localizado na região norte do Brasil, foi caracterizado pela metodologia de Thornthwaite e Matter (1955) como B1rA'a 'para uma CAD de 140 mm, ou seja, um clima úmido com média anual de chuvas de $2227 \mathrm{~mm}$ e evapotranspiração real de $1660 \mathrm{~mm}$, com pequena deficiência hídrica nos meses de junho a outubro, sem deficiência térmica, e o verão concentrado em três meses com temperatura média do ar de $25^{\circ} \mathrm{C}$ variando entre $18{ }^{\circ} \mathrm{C}$ e $32^{\circ} \mathrm{C}$. A menor temperatura de $18,2{ }^{\circ} \mathrm{C}$ foi observada em julho e a mais alta, de $32,1^{\circ} \mathrm{C}$, em agosto.

Palavras-chave: balanço hídrico climatológico, caracterização climática, armazenamento de água no solo, déficit hídrico.

\section{Introduction}

Knowledge of the interaction between natural elements can be necessary for the development of several sectors due to its influence on the climate of the region. (Mendonça, 2007) Plans for engaging agricultural activities are directly correlated with climatic conditions. (Nobre et al., 2013; Rind, 2002). Water deficit is the main factor that reduces agricultural productivity, making essential the knowledge of the spatial and temporal water availability of a region, through which it is possible to establish directives and implement water resource management policies (Leite et al., 2015). According to Pereira e Vicente, (2010), the climatological water budget (CWB) is significantly essential for plantation planning, irrigation management, agricultural zoning, and water resource management in a river basin.

The temporal distribution of climate variables can be obtained through the climatological water budget (CWB) developed by Thornthwaite and Mather (1955). This technique allows us to define the water regime of a given region through the available water capacity (AWC). (Andreae et al., 2015). Assuming an estimate of the amount of water available to the plants and indicating times of critical drought in the annual period. (Farias et al., 2017; Gurski et al., 2018).

The monthly temporal variation of precipitation is one of the main components of the climate and essential for the CWB. The monthly and annual total rainfall are distributed, allowing a careful analysis of the events, apart from those that occur in regions in which the annual rainfall is inferior to $750 \mathrm{~mm}$, which makes the analysis difficult due to the scarcity of climatic data over a long period. (Ayoade et al., 2011).

The municipality of Cruzeiro do Sul, located in the northern region of Brazil, is located close to an equator, thus receiving solar radiation throughout the year, keeping it very hot, having a strong influence of the large and flowing rivers that are located in the region and that, when receiving this amount of sunlight, evaporate the large amount of water into an atmosphere. These factors make the municipality have more precipitation rates in Brazil, with rainfall ranging from 2300 to $2800 \mathrm{~mm}$, such as heavy rains with high calorie rates and water availability combined with trade winds due to the location of regions that can be classified as convective (Silva, 2009). The northern region has a climate peculiar to other regions of the world, observing whether the literature lacks a detailed characterization of the climate of the municipalities it comprises.

Based on the information mentioned above, the importance of studying the periods of water deficit is evident, demanding the use of controlled irrigation. Therefore, this work aimed at identifying and quantifying the months of water surplus and deficit through the CWB of Thornthwaite and Mather (1955) to characterize the climate for Cruzeiro do Sul - AC and analyze the temporal distribution of the rainfall for the municipality.

\section{Material and Method}

The municipality of Cruzeiro do Sul is located in the northwest region of Acre, Brazil, on the left bank of the river Juruá, $648 \mathrm{~km}$ from the state capital, Rio Branco, at a latitude of $07^{\circ} 37^{\prime} 51^{\prime \prime} \mathrm{S}$, a longitude of $40^{\circ} 12^{\prime \prime} \mathrm{W}$, and an average altitude of $182 \mathrm{~m}$.

The climatic elements required to conduct the climatological water budget (CWB) were extracted from a 45year historical series of climatological data, comprising the years from 1970 to 2016, obtained from the meteorological database of the National Institute of Meteorological (INMET, 2017). We determined the climatological water budget and climatic classification according to Thornthwaite's methodology (Thornthwaite and Mather, 1955).

We estimated the available water capacity (AWC) using the field capacity (CC) and soil density (ds) of the region. (Coelho, 2016). The Vale do Juruá Region exhibits a great diversity of soils, where the soils that stand out are: Argisolos (65\%), accompanied by Luvisolos (19\%). In the municipality of Cruzeiro do Sul, the most prevalent soils are Gleissolos and Neossolos Flúvicos (Acre, 2010b).

We considered the daily precipitation and temperature data for correction and correction of faults in the data presented in the historical series used, the simple arithmetic mean methods and the method or method of the normal ratio in major faults are applied with a selected linear regression with the absolute minimum. (Teegavarapu and Chandramouli, 2005). 
We calculated the potential evapotranspiration (ETo) values using the method Hargreaves Samani (1985) evapotranspiration is given as a function of the monthly average temperature in ${ }^{\circ} \mathrm{C}$ and the thermal indices calculated as a function of the temperature acquired during the period, Eq. (1)

$$
\begin{gathered}
\text { ETo }(\mathrm{mm})=0,0023 \text {. Ra. }(\operatorname{Tmax}-\operatorname{Tmin})^{0.5} . \\
(\text { Tmed }+17.8)
\end{gathered}
$$

where $\mathrm{Ra}$ - radiation at the top of the atmosphere; Tmax, Tmin, Tmed - maximum, minimum and average temperature.

The estimated reference evapotranspiration values are representative for a month with 30 days, in which each day would have 12 hours of photoperiod, thus requiring correction according to the photoperiod and the latitude of the location. Correcting the number of days of the month (ND) by the photoperiod of the day that can be calculated or tabulated. Where: ETp is the potential or reference evapotranspiration $\left(\mathrm{mm} \mathrm{month} \mathrm{h}^{-1}\right)$; The average monthly temperature $\left({ }^{\circ} \mathrm{C}\right)$; I and a are thermal indices, which can be calculated by Eqs. (2)-(3)-(4) respectively or obtained. The photoperiod of the day that can be calculated or tabulated.

$$
\begin{gathered}
\operatorname{ETp}(\mathrm{mm})=16\left(10 \cdot \frac{\mathrm{Tm}}{\mathrm{I}} \cdot\right)^{\mathrm{a}} \\
\operatorname{cor}=\frac{\mathrm{ND}}{30} \cdot \frac{\mathrm{N}}{12}
\end{gathered}
$$

ETo $(\mathrm{mm})=$ ETp. cor

In sequence calculated and water storage in the soil (ARM), due to the monthly water deficit in the municipality, in the months when there was no water deficit in the region, the following procedure was adopted: the positive value of monthly precipitation (PPT) subtracted the monthly evapotranspiration (ETP) was added to the storage of the previous month, obtaining storage in the referred month. This procedure was adopted while "P - ETo" was positive. However, the maximum storage value is the $\mathrm{CAD}$ itself, which cannot be exceeded. The value of the storage column (ARM) for months with negative P - ETP is calculated using the Eq. (5).

$$
\mathrm{ARM}=\mathrm{CAD} \cdot \mathrm{e}^{\left(\frac{\text { (neg.acum }}{\mathrm{CAD}}\right)}
$$

In the real evapotranspiration (ETR), for months with soil water storage deficit, Eq. (6) was used and for months when storage was the same as CAD, ETR was the same as ETo.

$$
\operatorname{ETR}(\mathrm{mm})=\mathrm{PPT}+/ \mathrm{ALT} /
$$

where PPT monthly precipitation; ALT, modulating soil water storage.
The calcula water deficiency the (DEF), deficiency quantifies the difference between ETP and ETR, and it can only occur in months with negative (P - ETP). In the months water surplus (EXC) the excess only occurs when the maximum storage is reached, and its value is equal to (P - ETP) minus the storage change (Pereira and Vicente, 2010).

There are several methods of climatic classification, however, one of the most comprehensive is Köppen (Kopen and Geiger, 1928), taking into account natural vegetation, changes over the years and the analyzes and the system always related to thermal / water limits the types of climate determined for different regions. Proposed by Trewartha (1954) determined types of climate for the United States and, in general, simplified the Köppen system (Carter and Mather, 1966). In Brazil, Setzer (1966) simplified the trewartha method (1954) to determine scalable types that occur in the state of São Paulo. More recently, the Köppen method has been modified for Australia (Stern et al., 2005). However, a classification proposed by Thornthwaite (Thornthwaite, 1948), a plant is not seen as an instrument for integrating climatic elements, but as a physical means by which it is possible to transport water from the soil to an atmosphere. Therefore, this author proposes the use of classifications based on cluster analysis (Tyron, 1939) in which it is possible to numerically determine the similarity between climates, considering more meteorological elements at the same time.

Thus, a type of climate is defined as dry or humid related to the water needs of the plants, that is, dependent on a water balance. Using an appropriate method for classification in different regions.

The climatic classification of Cruzeiro do Sul was done according to the Thornthwaite (1955), based on the estimation of the humidity (Iu = Water Surplus/Evapotranspiration potential), aridity $(\mathrm{Ia}=$ Water Deficit/Evapotranspiration potential), moisture effect $(\mathrm{Im}=$ moisture content - 0.6 x Aridity Index), and thermal efficiency (TE) indices which consists of the amount of annual evapotranspiration of a region, as well as their seasonal variations $(C . v)$. the seasonal variation throughout the year is defined by the relationship between potential evapotranspiration in summer and annual evapotranspiration, due to the little variation in radiation throughout the year in this region, it is recommended to use concentrated evapotranspiration from december, january and february for the hemisphere South. The analyzed locations are classified in a key as to the climate through a formula composed basically of four upper and lower case letters.

We performed the temporal rainfall distribution using a municipal rainfall histogram constructed through the probability of occurrences (F) obtained by the increasing data ordering method, and the cumulative empirical distribution $[\mathrm{m} /(\mathrm{n}+1)]$, Kimbal's method, where " $\mathrm{m}$ " is 
the order number and " $n$ " is the number of data in the series. The mean recurrence interval $(\mathrm{T})$ in years was obtained through the equation $(\mathrm{T}=1 /(1-\mathrm{P}))$, in function of increasing data ordering, as suggested by (Gambús et al., 2007) We estimated the probability analysis and the return period using values superior to the average annual rainfall value.

\section{Results}

Cruzeiro do Sul presented monthly means of air temperature ranging from 18 to $32{ }^{\circ} \mathrm{C}$ and total means between 21 and $23{ }^{\circ} \mathrm{C}$, presenting the lowest temperature of $18,2{ }^{\circ} \mathrm{C}$ in July and highest of $32,1{ }^{\circ} \mathrm{C}$ in August (Fig. 1).

The extension located between the tropics of Cancer and Capricorn is considered a tropical region which is divided into tropical dry and tropical humid, the latter characterized by high humidity and constant temperatures with an average of $25{ }^{\circ} \mathrm{C}$ (Andreae et al., 2015). Sátori et al. (2009), based on climatological data of air temperature from 1992 obtained from INMET, observed average temperatures between 24 and $26{ }^{\circ} \mathrm{C}$ for the Amazon region, with annual amplitudes between 1 and $2{ }^{\circ} \mathrm{C}$. According to Viana and Herdies (2018), the low temperatures in the Amazon Basin from June to August can be attributed to cold air incursions during the austral winter. These polar air masses enter the Amazon forest from transient systems or cyclones.

The results of the climatological water budget are presented in Table 1 with the monthly averages of Temperatures $\left({ }^{\circ} \mathrm{C}\right)$, Evapotranspiration $(\mathrm{mm})$, and Rainfall (mm) from 1970 to 2016. It is observed that T, P, ETP, ETR, EXC and DEF are dependent on each other. Thus, it appears that the final part of the syorthology of the Thorthwaite system, resulting from temperature and the calculated elements of the water balance, has great weight in determining the climate. It can then be said that the Thornthwaite system is able to efficiently summarize the information generated by normal or average water balances.

Santos et al. (2017) used the monthly water balance methodology in their studies, and state that it is presumably to determine a water resource management project for the region in which this methodology is applied, facilitating the irrigation management. The determination of the time and quantity provided by the CWB stands out as an essential tool for deciding on the acquisition of irrigation systems and calculation of the required blade (Leite et al., 2015). The potential evapotranspiration (PET) estimated for the region was of $1774.46 \mathrm{~mm}$, representing a monthly average of $147.9 \mathrm{~mm}$, with the months of highest and lowest evapotranspiration occurring in October and June, respectively, with 164.9 and $129.7 \mathrm{~mm}$, respectively.

We determined the soil water storage using the available water capacity, adopting $140 \mathrm{~mm}$ as the maximum storage capacity, $1623.36 \mathrm{~mm} /$ year of real evapotranspiration registered, with a monthly average of $135.28 \mathrm{~mm}$. These results corroborate the studies conducted by Alves Sobrinho et al. (2011), who employed the calibration of the evapotranspiration estimation equations, using a climatological series from 1961 to 1990 for 47 locations in the Northern region of Brazil, finding averages of approximately $130 \mathrm{~mm} / \mathrm{month}$.

The water replenishment in the soil occurs between November and April. However, we verified a water deficit from June to September, which covers the dry season in the region. A few authors who conducted studies with his-

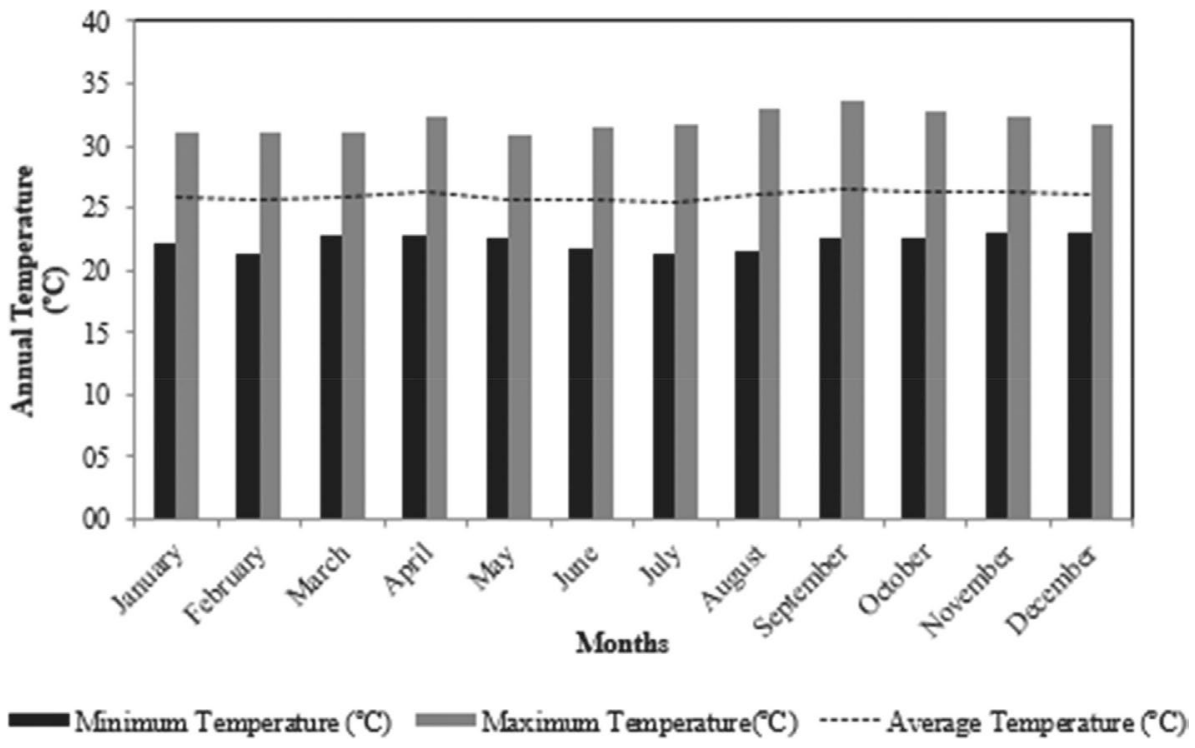

Figure 1 - Annual characterization of maximum, minimum and average temperatures of Cruzeiro do Sul - AC, Brazil. 
Table 1 - Climatological water budget (in mm) of the municipality of Cruzeiro do Sul - AC, Brazil, from 1970 to 2016, according to Thornthwaite, considering a soil AWC of $140 \mathrm{~mm}$.

\begin{tabular}{|c|c|c|c|c|c|c|c|c|c|}
\hline Month & $\mathrm{T}\left({ }^{\circ} \mathrm{C}\right)$ & Rain (mm) & ETP (mm) & P-ETP & NEG. & STO & ETR & DEF & SUR \\
\hline Jan. & 25.1 & 249.6 & 155.0 & 94.6 & 0 & 140 & 155.0 & 0 & 94.6 \\
\hline Feb. & 25.1 & 249.7 & 138.5 & 111.1 & 0 & 140 & 138.5 & 0 & 111.1 \\
\hline Mar. & 25.1 & 288.6 & 149.6 & 139.1 & 0 & 140 & 149.6 & 0 & 139.1 \\
\hline Apr. & 25.2 & 226.2 & 140.0 & 86.2 & 0 & 140 & 140.0 & 0 & 86.2 \\
\hline May & 25.0 & 154.1 & 135.0 & 19.1 & 0 & 140 & 135.0 & 0 & 19.1 \\
\hline Jun. & 25.0 & 90.9 & 129.7 & -38.8 & -38.8 & 106.1 & 124.8 & 4.9 & 0.0 \\
\hline Jul. & 25.0 & 66.0 & 141.6 & -75.6 & -114.4 & 61.8 & 110.3 & 31.3 & 0.0 \\
\hline Aug. & 25.4 & 80.1 & 153.6 & -73.5 & -187.9 & 36.6 & 105.4 & 48.3 & 0.0 \\
\hline Sep. & 25.6 & 117.0 & 155.5 & -38.5 & -226.4 & 27.8 & 125.8 & 29.7 & 0.0 \\
\hline Oct. & 25.6 & 194.0 & 164.9 & 29.1 & -68.87 & 56.9 & 164.9 & 0 & 0.0 \\
\hline Nov. & 25.4 & 214.4 & 154.9 & 59.5 & 0 & 116.4 & 154.9 & 0 & 0.0 \\
\hline Dec. & 25.1 & 243.2 & 156.2 & 86.9 & 0 & 140 & 156.2 & 0 & 63.3 \\
\hline Year & & 2173.7 & 1774.5 & 399.3 & & & 1660.4 & 114.13 & 513.5 \\
\hline
\end{tabular}

torical rainfall series in the Amazon show decade and inter-decade rainfall variability, which can be extended or reduced.(Paiva, 2009; Cai et al., 2005; Matsuyama, 1992; Nobre et al., 2013). Figure 2 shows that from November to January, the rainfall was higher than the potential evapotranspiration. On the other hand, from June to September, the rainfall is reduced, and the evapotranspirotion demand increases, indicating a water deficit in Cruzeiro do Sul for 4 months.

The water replenishment in the soil occurred in November. However, the rainfall superior to the potential evapotranspiration values begins in October, with the water surplus beginning only in December. The period of water surplus begins after the water replenishment period, characterizing soil saturation. The prolonged period of soil saturation causes a decrease in crop yield due to root asphyxiation, increased soil temperature, and proliferation of diseases caused by fungi, in addition to providing sur-

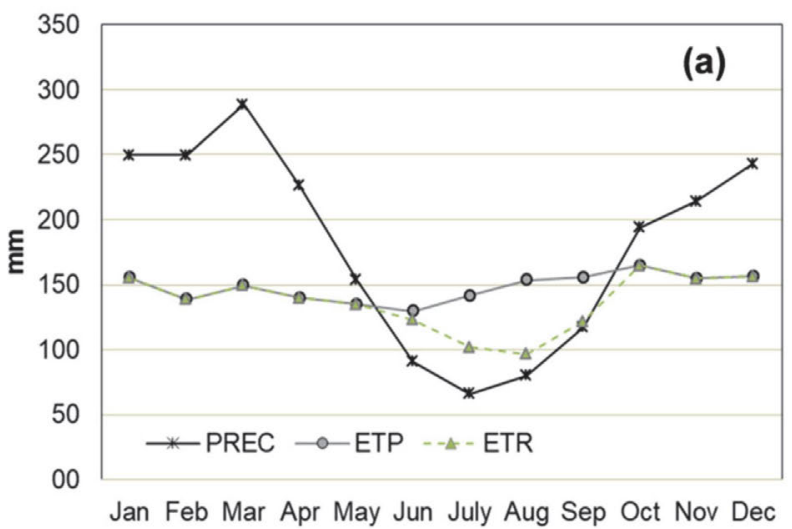

face runoff and erosion in soils with steep slopes (Andreae et al., 2015).

The nomenclature of Thornthwaite clearly indicates that " $\mathrm{C}$ and $\mathrm{D}$ " climates are less rainy, however " $\mathrm{A}$ and B" climates are rainy and moderately, with averages above $125 \mathrm{~mm} /$ month, regarding the aspects of temperature and annual temperature accumulation, the Thornthwaite system shows great sensitivity in differentiating climatic types. The Thornthwaite characterization system was very sensitive to ETP variations as well as to the climatic elements resulting from the normal water balance (DEF, SUR), verifying that " $\mathrm{C}$ " climates are drier, with average SUR of $25 \mathrm{~mm} /$ month. The "B" climates are moderately dry and the " $A$ " climates with higher surpluses, reaching a There was sensitivity in the system, mainly with regard to the thermal factor, which makes up the final part of the formulation of the type of climate.

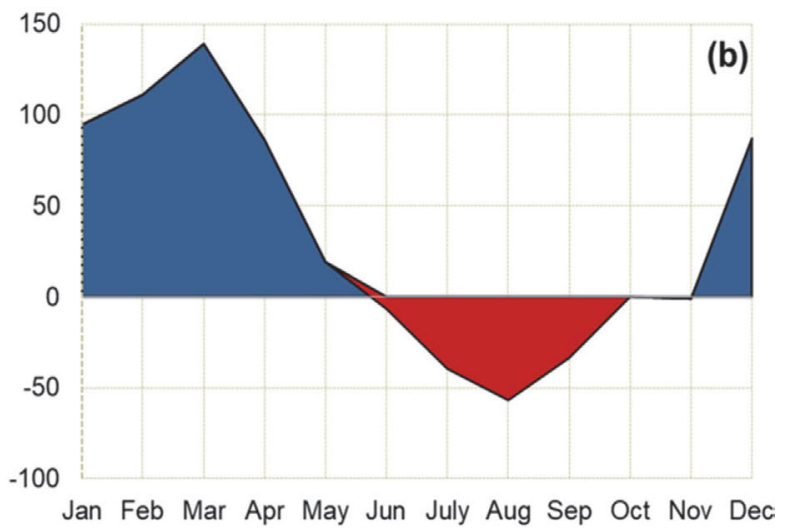

Figure 2 - (a) Variation of the meteorological rainfall (RAIN), potential evapotranspiration (ETP), and real evapotranspiration (ETR), ( b) Deficit water, CAD $100 \mathrm{~mm}$. 
Table 2 - Thornthwaite índices (1948) and climatic classification for Cruzeiro do Sul - AC, Brazil.

\begin{tabular}{lcccc}
\hline $\mathrm{Im}$ & $\mathrm{Ia}$ & $\mathrm{Iu}$ & $\mathrm{TE}$ & $\mathrm{Cv}$ \\
\hline 25.08 & 6.43 & 28.94 & 1774.46 & 25.34 \\
\hline Climatic type & & Climatic classification & Climatic subtype \\
\hline $\mathrm{B}_{1 \text { humid }}$ & Seasonal variation & Thermal deficiency & a' \\
\hline
\end{tabular}

According to the climatological water budget for a $140 \mathrm{~mm}$ AWC (Table 1), the climatic classification for Cruzeiro do Sul is B1rA'a', characterized by a humid climate with a small water deficit from June to October, with no thermal deficiency, with climatic subtype a ', indicated summer concentrated in three months of the year. (Table 2).

Figure 3 shows that the average monthly rainfall ar concentrated from October to May, with an average of $230 \mathrm{~mm}$ and a maximum value of $288 \mathrm{~mm}$ (March). July presents the lowest rainfall $(66 \mathrm{~mm})$ and is considered the beginning of the water deficit period in the municipality, which ends in October when the soil water reposition process begins.

When analyzing the primary aspects that characterize the climate in the Amazon region in an NW-SE band, Poveda and Salazar, (2004), identified that rainfall increases over the Amazon Basin during the austral spring. The mass development is associated with tropical convection in the west of the basin and rainfall activity in the extratropics. Hirota et al. (2010) observed that maximum va- lues near $10^{\circ} \mathrm{S}$ extend to the southwest, receiving $50 \%$ of the total rainfall in the austral summer season.

According to Santos et al. (2017) and Sobrinho et al. (2011), the spatial and temporal variability of rainfall in Brazil controls socioeconomic activities. The income from agricultural activities of the municipality of Cruzeiro do Sul represents $86 \%$, which directly depends on the rainfall well distributed throughout the year.

The histogram generated based on the rainfall data from the years 1970 to 2016, shows The municipality of Cruzeiro do Sul presented a concentrated annual average of $2300 \mathrm{~mm}$, confirming the regional dynamics.that the highest annual rainfall recorded was of $2848.1 \mathrm{~mm}$ in 1990 , and the lowest was of $1401 \mathrm{~mm}$ in 1981 . The average annual rainfall in Cruzeiro do Sul is of $2,227 \mathrm{~mm}$, with a higher frequency observed remaining between $2100 \mathrm{~mm}$ and 2300 (Fig. 4).

The maximum annual rainfall of Cruzeiro de Sul is associated with its location in the convergence zone of the eastern moisture flow, resulting from the presence and concavity of the Andes (Nobre et al., 2013).

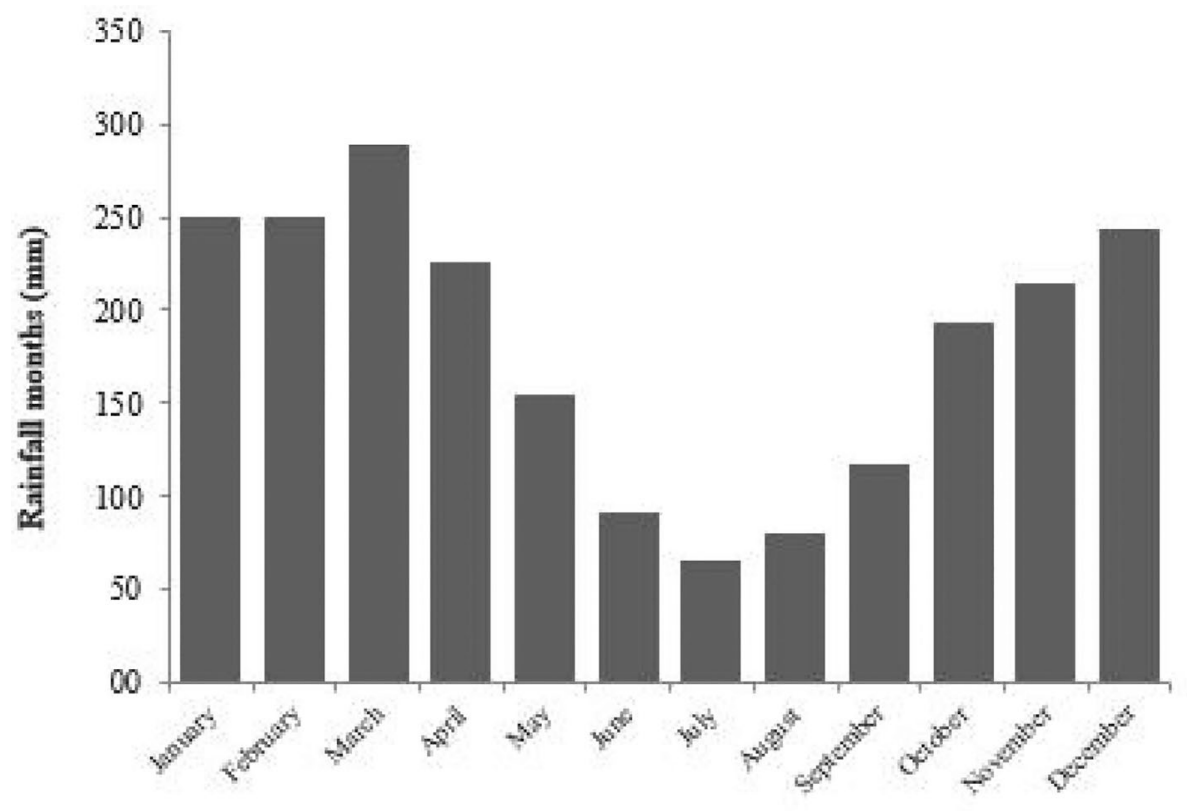

Figure 3 - Monthly rainfall distributed over the year for Cruzeiro do Sul, AC, Brazil, calculated based on the climatological series of 1970-2016. 


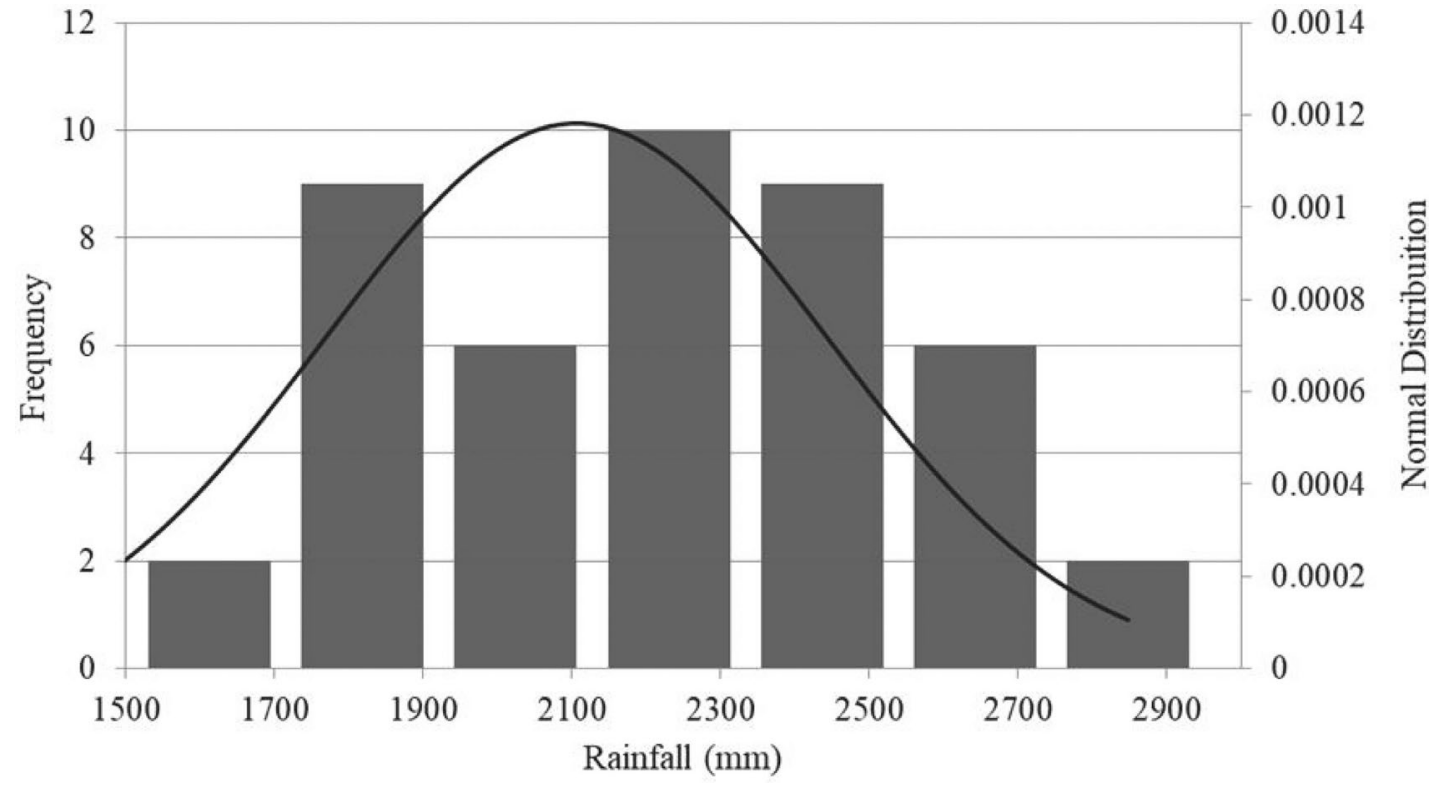

Figure 4 - Histogram and normal distribution of the annual rainfall values for Cruzeiro do Sul, AC, Brazil.

Marengo (2007) attributed the high rainfall of the northern region to the result of the dynamic fluctuation of the permanent convection center in combination with the high evapotranspiration of the forest which contributes to the rainfall. The modular patterns of rainfall recycling in the municipality can be attributed to the stimulation of seasonal and daily cycles of solar energy (Kang and Elthair, 2018).

\section{Conclusions}

The climate in Cruzeiro do Sul-Acre, Brazil, was characterized as B1rA'a', a humid climate with a small water deficit, no thermal deficiency, and a summer concentrated in three months of the year.

The wet and dry seasons for the region of Cruzeiro do Sul are well characterized by the rainfall averages. The maximum rainfall is concentrated in October, November, December, January, February, March, April, and May.

The water replenishment begins in November, and the water surplus occurs between December and April extending until May, followed by the beginning of the water deficit period.

The water deficit in the municipality of Cruzeiro do Sul occurs in the months of June, July and August.

The annual average rainfall is of $2227 \mathrm{~mm}$ with an annual mean temperature of $25{ }^{\circ} \mathrm{C}$ and real evapotranspiration of $1660 \mathrm{~mm}$.

The municipality presents water deficiency in 4 months of the year, justified by the high temperatures that cause an increase in the evapotranspiration rates, and water consumption by the plants superior to the water available in the soil in these months.

\section{References}

ACRE. Governo do Estado do Acre. Zoneamento Ecológico Econômico do Estado do Acre, Fase II (Escala 1:250.000): Documento Síntese. 2. Ed. Rio Branco: SEMA, 356 p., 2010 b.

ALVES SOBRINHO, T.; RODRIGUES, D.B.B.; OLIVEIRA, P.T.S.; REBUCCI, L.C.S.; PERTUSSATTI, C.A. Estimativa da evapotranspiração de referência através de redes neurais artificiais. Revista Brasileira de Meteorologia, v. 26, n. 2, p. 1-13, 2011.

ANDREAE, M.O.; ACEVEDO, O.C.; ARAÙJO, A.; ARTAXO, P.; BARBOSA, C.G.G.; et al. The Amazon Tall Tower Observatory (ATTO) in the remote Amazon Basin: overview of first results from ecosystem ecology, meteorology, trace gas, and aerosol measurements. Atmospheric Chemistry and Physics, v. 15, n. 18, p. 10723-10776, 2015.

AYOADE, A.; OGUNWALE, A.; ADEWALE, J. Impact of the national special programme for food security on poverty alleviation among women in Oyo State, Nigeria. African Journal Food Agriculture Nutrition, v. 11, n. 4. p. 1-18, 2011.

CAI, Y.; ZHOU, Y.; CHEN, K.J.; LAU, K.M. Self-aligned enhancement-mode AlGaN/GaN HEMTs using fluoridebased plasma treatment, 63rd Device Research Conference Digest, 2005. DRC ‘05, Santa Barbara, p. 179-180, 2005

CARTER, D.B.; MATHER, J.R. Climatic Classification for Environmental Biology. Elmer: Thornthwaite Associates Laboratory of Climatology, 1966. 395 p.

COELHO, V.H.R. Estimativa da Recarga Subterrânea em Bacia Hidrográfica do Semiárido Pernambucano a Partir de Técnicas de Sensoriamento Remoto e Sistemas de Informações Geográficas. Tese de Doutorado em Engenharia Civil, Universidade Federal de Pernambuco, Recife, 2016. 
FARIAS, V.D.D.S.; LIMA, M.J.A. DE.; NUNES, H.G.G.C.; SOUSA, D.D.P.; SOUZA, P.J.D.O.P. DE. Water demand, crop coefficient and uncoupling factor of cowpea in the eastern amazon. Revista Caatinga, v. 30, n.1, p. 1-10, 2017.

GAMBUS, HALINA; SIKORA, MAREK; ZIOBRO, RAFAL. The effect of composition of hydrocolloids on properties of gluten-free bread. Acta Science Pol. Technology Aliment, v. 6. n.3, p. 61-74, 2007.

GURSKI, B.C.; JERSZURKI, D.; DE SOUZA, J.L.M. Alternative methods of reference evapotranspiration for Brazilian climate types. Revista Brasileira de Meteorologia, v. 33 n. 3 p. 1-15, 2018.

HIROTA, M.; NOBRE, C.; OYAMA, M.D. BUSTAMANTE, M.M.C. The climatic sensitivity of the forest, savanna and forest-savanna transition in tropical South America. New Phytological, v. 187, n. 3 Special Issue. 2010.

KANG, S.; ELTAHIR, E.A.B. North China Plain threatened by deadly heatwaves due to climate change and irrigation. Nature Communications, v. 9, n. 2894, 2018.

KÖPPEN, W.; GEIGER, R. Klimate Der Erde. Gotha: Verlag Justus Perthes. 1928. Wall-map $150 \mathrm{~cm} x 200 \mathrm{~cm}$. https:// doi.org/S0006-8705200700040002200006\&lng=en.

LEITE, K.N.; MARTÍNEZ-ROMERO, A.; TARJUELO, J.M.; DOMÍNGUEZ, A. Distribution of limited irrigation water based on optimized regulated deficit irrigation and typical metheorological year concepts. Agriculture Water Management, v. 148, n. 31, p. 164-176, 2015.

MARENGO, J.A. Mudanças Climáticas Globais e seus efeitos sobre a biodiversidade caracterização. Revista Biodiversidade, v. 26. n. 2, p. 1-10. 2007.

MATSUYAMA, K. Agricultural productivity, comparative advantage, and economic growth. Journal of Economic Theory, v. 58, n. 2, p. 317-334, 1992.

MENDONÇA, D. Decision support for improvisation in response to extreme events: Learning from the response to the 2001 World Trade Center attack. Decision Support Systems, v. 43, n. 3, p. 952-967, 2007.

NOBRE, C.A.; OBREGÓN, G.O.; MARENGO, J.A.; FU, R.; POVEDA, G. Characteristics of Amazonian climate: Main features. In: Amazonia and Global Change. Washington: American Geophysical Union, p. 149-162, 2013.

PAIVA, R.C.D. de. Modelagem hidrológica e hidrodinâmica de grandes bacias. Estudo de caso: Bacia do Rio Solimões. Dissertação de Mestrado, UFV, 2009.

PEREIRA, R.N.; VICENTE, A.A. Environmental impact of novel thermal and non-thermal technologies in food pro- cessing. Food Research International, v. 43, n. 7, p. 1936194, 2010.

POVEDA, G.; SALAZAR, L.F. Annual and Interannual (Enso) Variability of Spatial Scaling Properties of a Vegetation Index (NDVI) in Amazonia. Journal of Geophysical Research, v. 107, n. 20, p.1-15, 2004.

RIND, D. Climatology: The Sun's role in climate variations. Science, v. 296 n. 5568 pp. 673-677, 2002.

SANTOS, J.; CEREZO, V.; FLINTSCH, G.; FERREIRA, A. 2017. Environmental and economic assessment of pavement construction and management practices for enhancing pavement sustainability, in: Transport Infrastructure and Systems. Proceedings of the AIIT International Congress on Transport Infrastructure and Systems, Rome, Italy, 10-12 April 2017.

SÁTORI, G.; WILLIAMS, E.; LEMPERGER, I. Variability of global lightning activity on the ENSO time scale. Atmospheric Research, v. 91, n. 2-4, p. 500-507, 2009.

SOBRINHO, T.A.; BUCHALA, D.; RODRIGUES, B.; TARSO, P.; DE OLIVEIRA, S. Estimativa da evapotranspiração de referência através de redes neurais artificiais. Revista Brasileira de Meteorologia, v. 26, n. 2, p.197-203, 2011.

SETZER, J. Atlas Climático e Ecológico do Estado de São Paulo. Comissão Interestadual da Bacia Paraná-Uruguai, 1966. 61p.

STERN, H.; HOEDT, G.; ERNST, J. Objective Classification of Australian Climates. Australia: Bureau of Meteorology. 2005. Disponível em: http://www.bom.gov.au/climate/ environ/other/koppen_explain.shtml, acesso em 16 abril 2019.

THORNTHWAITE, C.W. An approach towards a rational classification of climate. Geographical Review, London, v. 38, p. 55-94, 1948.

THORNTHWAITE, C.W.; MATHER, J.R. The Water Balance. Centerton: Drexel Institute of Technology, 1955.

TREWARTHA, G.T. An Introduction to Climate. New York: McGraw-Hill, 402 p., 1954.

TYRON, R.C. Cluster Analysis. Ann Arbor: Edwards Brothers, 1939.

VIANA, L.P.; HERDIES, D.L. Case study of a cold air outbreak incursion extreme event in July 2013 on Brazilian Amazon Basin. Revista Brasileira de Meteorologia, v. 33 n. 1, p. 27-39, 2018.

License information: This is an open-access article distributed under the terms of the Creative Commons Attribution License (type CC-BY), which permits unrestricted use, distribution and reproduction in any medium, provided the original article is properly cited. 